\title{
Питання психології
}

УДК: $321.51+355.09$

DOI: $10.33099 / 2617-6858-21-59-1-131-137$

Кримець Л. В. доктор філософських наук, старший науковий співробітник, провідний науковий співробітник

НДЛ (сочіально-гуманітарних проблем) кафедри суспільних наук Національного університету оборони України імені Івана Черняховського https://orcid.org/0000-0001-7451-5208

\section{ПРИНЦИП ПАТРІОТИЗМУ У КОНТЕКСТІ АКТУАЛІЗАЦІЇ ЄВРОАТЛАНТИЧНИХ ЦІННОСТЕЙ У ЗБРОЙНИХ СИЛАХ УКРАЇНИ}

\begin{abstract}
Впровадження етичних засад та євроатлантичних иінностей у військово-професійному середовищі Збройних Сил Украӥни вимагає корегування як усієї сфери професійних відносин, так $i$ врахування безпосереднього впливу на формування образу мислення та поведінки суб'єктів ичих відносин. На інтернаціональному рівні принцип патріотизму розкривається через иінності єдності $і$ вірності колективу, військовій організації, країнам-членам та партнерам, інтересам Альянсу, інтернаціональним зобов'язанням та людству в иілому. Тобто, на шляху до євроатлантичної інтегращії принии патріотизму набуває інтернаціонального наповнення $і$ вимагає розширення світогляду та формування критичного мислення $i$ відповідних етичних переконань військовослужбовиів Збройних Сил Украӥни.
\end{abstract}

Ключові слова: патріотизм; вірність; євроатлантичні иінності; професійна етика; демократизачія украӥнського війська; військова діяльність.

Вступ.

На сучасному етапі суспільного розвитку у збройних силах більшості держав існує розуміння того, що для підвищення якості функціонування військової організації необхідно розвивати військову етику як джерело та рушійну силу професійного та особистісного розвитку військовослужбовців та працівників збройних сил [1].

Проблеми формування етичних засад військової діяльності в Україні на основі європейських та євроатлантичних цінностей виступають важливим чинником демократизації та гуманізації суспільних сфер у нашій державі. Етичні цінності $\epsilon$ визначальною стимуляційно-мотиваційною базою різноманітної діяльності людей, соціальних груп суспільства. Особлива їх роль проявляється у суспільствах, які прагнуть змін демократичного характеру. Сьогодні в Україні переважає єдність щодо необхідності впровадження демократичних реформ, українську націю зміцнюе іiі демократичний поступ через реалізацію свободи слова, підтримку громадянського суспільства та захист прав людини. [2].

Патріотизм, як одна 3 найвагоміших морально-етичних цінностей особистості $€$ невід'ємним атрибутом існування нації, народу, суспільства, держави, він являє собою найважливішу умову єдності, культурної цілісності, динамічного i успішного розвитку людства. Але це не єдина умова їх існування та розвитку, тому він не повинен абсолютизуватися, і в той же час феномен патріотизму не варто ігнорувати у процесі націотворення, бо він культурно і соціально незамінний [3].

\section{Теоретичне підгрунтя.}

Значний інтерес для розуміння проблеми патріотизму, його формування i ролі в сучасній українській науковій думці представляє література останніх двадцяти років. За цей час з'явилось чимало робіт, які характеризуються творчим, дослідницьким підходом до осмислення проблеми у всій іiі глибині і складності. Наявність значної кількості літератури 3 даної проблеми свідчить про певний інтелектуальний прорив в осмисленні іï найбільш істотних сторін завдяки активізації відповідних досліджень в галузі філософських, історичних, політологічних, соціологічних, психологічних наук. Тим самим створено певний заділ для продовження теоретичних досліджень 3 цілого ряду найважливіших аспектів проблеми, здійснення системного аналізу патріотизму як складного соціального феномену та умов його розвитку в сучасному українському суспільстві.

У проблемне поле наукових досліджень включені такі питання, як переоцінка 


\section{Питання психології}

цінностей, зміна ціннісних підстав ідентифікації, відношення до патріотизму різних соціальних груп, роль патріотичних цінностей у формуванні громадської думки та ін. Особливий інтерес представляють роботи щодо розробки методології і теорії системних особливостей українського суспільства, духовного життя, етнічних процесів, соціального прогнозування та моделювання суспільного розвитку - В. Андрущенко, Ю. Бадзьо, А. Бичко, М. Верникова, Р. Додонова, А. Кавалерова, Л. Кримець, О. Пунченко, М. Слюсаревського, Л. Снігур, В. Тарасенко, В. Шинкарука, С. Ярмуся та ін.. Ці дослідження допомагають зрозуміти і дослідити місце і роль патріотизму в умовах сучасної української дійсності [3].

Проблема відношення до Батьківщини в якості предмета наукового аналізу традиційно привертала i продовжує привертати увагу не тільки вітчизняних, але й зарубіжних дослідників. Слід зазначити, що в західній науці, у роботах Ж.Леньяна та В.Тюне крім загальної iї постановки, простежується також прагнення вчених розглядати різні пов'язані з нею питання 3 точки зору спадкоємності національнодержавного розвитку своєї країни i в контексті іiі культурно-історичної традиції [4]. Американський вчений Л. Доуб проаналізував психологічні основи патріотизму у співвідношенні 3 іншим феноменом масової свідомості націоналізмом [5; С. 62-66].

3 огляду на вищенаведене підкреслимо, що ступінь загальнотеоретичної розробки проблеми патріотизму в Україні все ще далекий від відповідності потребам нашого часу. Також має місце слабка орієнтація наукових досліджень на вирішення найважливіших завдань практичного характеру, пов'язаних 3 формуванням ментальності особового складу Збройних Сил України на засадах демократичних цінностей та розвитком у громадянському суспільстві національної ідентичності, високої громадянської культури та державного патріотизму.

\section{Методи дослідження.}

Автор виходить 3 позицій соціокультурного підходу про те, що зміна зовнішніх умов, середовища неминуче тягне за собою зміни (позитивні, або негативні) внутрішнього світу особистості, особистісних утворень, тобто зміна мотиваційно-ціннісної сфери особистості під впливом соціокультурних чинників призводить до трансформації етичних поглядів та переконань. В сучасному українському суспільстві, у зв'язку 3 анексією Кримського півострова та Операцією об'єднаних сил на Сході України, проблема формування патріотичної моральної свідомості українських громадян, а особливо, військовослужбовців, як основи для актуалізації процесів націотворення набула особливої гостроти [2].

\section{Результати обговорення.}

Важливо зазначити що у процесі реформування Збройних Сил України на шляху до підвищення ефективності виконання ними основних завдань: оборони України, захисту іiі суверенітету, територіальної цілісності та недоторканності, - саме патріотизм $\epsilon$ найвагомішим принципом, що закладається в фундамент сучасної військової етики.

Відповідно до Візії Генерального штабу щодо розвитку Збройних Сил України на найближчі 10 років, Збройні Сили України повинні користуватися повагою серед населення країни, союзників, слідувати своїм традиціям, бути укомплектованими підготовленим, мотивованим персоналом, озброєними сучасним озброєнням та військовою технікою, спроможними діяти самостійно та спільно з партнерами України [6].

Основними принципами розвитку ЗС України відповідно до Візії є:

Патріотизм - $\quad$ відстоювання національних інтересів держави, повага та любов до Батьківщини, iii державних символів, національних цінностей, культури, історії, української мови, ідейна переконаність, відданість, готовність до самопожертви заради свободи та незалежності українського народу;

верховенство права - забезпечення законності, підзвітності, прозорості та дотримання засад справедливості i демократичного цивільного контролю за функціонуванням сектору безпеки i оборони;

єдиноначальність - наділення командира (начальника) всією повнотою влади стосовно підлеглих та покладання на нього персональної відповідальності 


\section{Питання психології}

перед державою за всі складові діяльності військової частини (підрозділу); надання командиру (начальнику) права одноосібно приймати рішення та віддавати накази; забезпечення виконання визначених рішень i наказів, виходячи із всебічної оцінки обстановки та вимог законів України; персональна відповідальність особиста та неподільна відповідальність військовослужбовця, незалежно від його посади та військового звання, за виконання покладених на нього обов'язків військової служби, дотримання військової дисципліни, виконання вимог нормативно-правових актів та керівних документів, які регламентують його діяльність і поведінку;

добропорядність - направленість дій військовослужбовця на захист національних інтересів івідмова його від пріоритетності власних інтересів під час виконання наданих йому повноважень, неприпустимість корупційних дій у будь-яких проявах, відкритість під час виконання обов'язків військової служби;

лідерство - сприяння прагненню до належного виконання службових обов'язків, кар'єрного зростання, набуття високого професійного рівня особовим складом, здійснення ефективної кадрової політики і створення відповідного військового резерву 3 урахуванням знань, бойового досвіду, умінь та навичок військовослужбовців під час їх призначення на керівні посади, згуртування військового колективу, його налаштування на працю;

гендерна рівність - забезпечення рівними можливостями, правами та обов'язками чоловіків та жінок під час проходження військової служби;

повага до військовослужбовців військовослужбовці є центром уваги вищого військово-політичного керівництва країни. Створення для них гідних умов щодо походження військової служби, надання всебічної підтримки суспільством [6].

Авторка цієї статті брала активну участь в розробці етичних засад військової діяльності, викладених у Візії розвитку Збройних Сил у складі робочої групи, тому дефініція принципу патріотизму, заявлена в Візії повністю співпадає 3 авторською позицією.

Наступним кроком у визначенні засадничих положень діяльності Збройних Сил України є розробка низки стратегічних документів, серед яких проекти Стратегії воєнної безпеки України та Стратегічного оборонного бюлетеня України. Слід зазначити, що відповідно до проекту Стратегічного оборонного бюлетеня України, затвердженого в Міністерстві оборони України 11 лютого 2021 року, нова філософія розвитку Збройних Сил України спрямована на досягнення конкретних спроможностей сил оборони з урахуванням результатів оборонного огляду. Крім того, проектом Стратегічного оборонного бюлетеня серед іншого передбачено, що за результатами реалізації завдань воєнної політики України сили оборони будуть відповідати вимогам ведення всеохоплюючої оборони України та побудовані на національних i євроатлантичних цінностях; будуть взаємосумісні з відповідними структурами держав-членів НАТО, а також спроможні забезпечити оборону території України у міжнародно визнаних кордонах [7].

В контексті вирішення поставлених завдань, важливо розуміти, які ж саме цінності і принципи складають основу етики Європейського Союзу та Північноатлантичного альянсу і окреслити шляхи їх інтеграції у професійну етику військовослужбовців ЗС України.

Проблеми європейських цінностей розглядали у своїх працях I. Бех, М.Боришевський, Р. Войтович, В. Гошовська, В. Князев, Л. Пашко, I. Сурай, М. Пірен [8]. Наступні цінності $€$ фундаментальними етичними засадами формування та розвитку Європейського Союзу, ці цінності описані в Лісабонському договорі та Хартії основних прав:

1. Людська гідність. Вона $\epsilon$ недоторканою, повинна поважитись i захищатись та є основою прав людини.

2. Свобода. Свобода пересування дає громадянам право подорожувати та проживати в будь-якій точці $\mathrm{EC}$. Індивідуальні свободи, такі як повага до приватного життя та свобода думки, релігії, зборів, вираження думок та інформації, захищені Статутом основних прав ЄС.

3. Демократія. Функціонування $\mathrm{CC}$ базується на представницькій демократії. Всі європейські громадяни мають політичні права. Кожен дорослий громадянин ЄС має право виступати як кандидат і голосувати на виборах до Європейського парламенту. 


\section{Питання психології}

Громадяни $\mathrm{CC}$ також мають право голосувати на виборах у країні, де вони живуть, або у країні їх походження.

4. Рівність. Під нею розуміється рівноправність вимог закону для всіх громадян. Принцип гендерної рівності між чоловіками та жінками $є$ основою європейської політики та європейської інтеграції. Вона застосовується у всіх областях. Принцип рівної оплати за рівну роботу законодавчо закріплений у 1957 році. Незважаючи на те, що існують певні проблеми, СС досяг значного прогресу в цій галузі.

5. Верховенство права. ЄС базується на верховенстві права: все, що він робить, базується на договорах, які добровільно та демократично приймаються країнами $\mathrm{CC}$. Закон i правосуддя здійснюються незалежною судовою системою. Країни СС надали право остаточної юрисдикції Європейському Суду, рішення якого повинні поважати всі сторони.

6. Права людини. Вони захищені Статутом основних прав СС і містять право залишатися вільними від дискримінації за ознакою статі, расової, етнічної приналежності, релігії, віросповідання, віком або сексуальною орієнтацією, право на захист персональних даних та на доступ до правосуддя.

Проте якщо мова йде про євроатлантичні цінності, важливо також враховувати, позицію НАТО щодо формування професійної етики військовослужбовців та працівників, що приймають участь в місіях під керівництвом НАТО та проходять службу в органах управління.

У 2013 році Рада Північноатлантичного альянсу затвердила етичний кодекс поведінки персоналу «The NATO Code of Conduct», обов'язковий до виконання i врахування в службовій діяльності країнами-членами та партнерами НАТО [9].

в кодексі «The NATO Code of Conduct» зазначено, що Організація Північноатлантичного альянсу (НАТО) передбачає сприяння найвищому рівню довіри між його членами та вимагає від них єдності, неупередженості, лояльності (вірності), відповідальності і професіоналізму. Ці п'ять основних цінностей складають основу етичного Кодексу, який визначає вимоги до поведінки всіх цивільних та військових співробітників та персоналу підрозділів НАТО [9]. 3 метою більш глибинного ознайомлення цільової аудиторії з етичними вимогами НАТО, пропонуємо огляд основних положень кодексу.

Згідно «The NATO Code of Conduct» Єдність має реалізовуватися як:

- чесність та правдивість у професійних відносинах;

- уникання ситуацій, які можуть призвести до реального сприйняття розгортання потенційних конфліктів між особистими (національними) інтересами та інтересами усього Альянсу.

- виконання негайних дій, щоб позбутися ситуацій де можуть відбутися конфлікти інтересів;

- заборона на використання публічної інформації, отриманої через офіційні джерела НАТО для особистої вигоди;

- уникання дій, які можуть сприйматися як зловживання привілеями та імунітетом, наданими Організацією його персоналу.

Вірність має бути спрямована на:

- підтримку принципів, на яких був заснований Альянс;

- демонстрацію єдності на шляху до досягнення мети, орієнтованої на реалізацію цілей та завдань організації;

- прагнення зробити особистий внесок в успіх НАТО та сприяння культурі результатів через Альянс;

- вимогу завжди ставити інтереси альянсу вище власних інтересів та інтересів окремих народів, пам'ятаючи про рівність усіх перед законом;

- формування, сприяння та підтримку позитивного командного духу.

Відповідальність як цінність та морально-етична вимога передбачає:

- відповідальність за власні дії, рішення, або бездіяльність і прийняття їх наслідків та результатів;

- оперативні дії для вирішення або виправлення будь-яких помилок або упущень, які члени альянсу зробили чи можуть зробити;

- прозорість професійної діяльності, навіть за умови іiї негативної оцінки;

- усвідомлення наслідків власних дій і рішень, до моменту їх прийняття;

- пильність щодо будь-яких шахрайств та зловживань, які можуть статися в 


\section{Питання психології}

організації та відповідна протидія ним належним чином;

- уникання будь-яких дій, які можуть призвести до пошкодження або ризику для Організації, ii комунікаційних та інформаційних систем або невідповідне використання і розголошення інформації.

Неупередженість як базова цінність проявляється через наступні вимоги:

дотримуватись принципів об'єктивності та незалежності у професійних операціях, прагнути бути чесними та справедливими у всіх аспектах діяльності;

- зберігати міжнародний погляд та використовувати рекомендації та рішення Альянсу в цілому не зважаючи на погляди чи інтереси власної або будь-якої конкретної країни або нації;

- не приймати подарунки, які можуть поставити під загрозу вашу неупередженість або породити сприйняття браку об'єктивності у вашій поведінці та виконанні службових обов'язків;

- Не займатися неавторизованою зовнішньою роботою чи іншими видами діяльності, що може суперечити чи заважати виконанню ваших службових обов'язків;

- Не використовувати позицію НАТО або привілейовану професійну інформацію про діяльність альянсу, не за призначенням та 3 метою отримати користь або забезпечити собі роботу в майбутньому після закінчення роботи в НАТО.

Професіоналізм як цінність військовопрофесійної діяльності декларується крізь призму вимог до цивільного та військового професіонала:

- покласти чесні зусилля на повсякденне виконання професійних обов'язків;

- підтримувати найвищий рівень компетенції у власній професійній сфері i прагнути до постійного вдосконалення професійних знань, навичок та вмінь;

- доглядати і обережно використовуйте обмежені ресурси своєї професійної організації;

- забезпечити безпеку та конфіденційність службової інформації;

- враховувати наслідки власної професійної діяльності щодо природного середовища;

• поважайте конфіденційність приватної сфери, та різноманітність усіх співробітників;
- не переслідувати та не дискримінувати інших співробітників у професійному середовищі, вимагати того ж від інших;

- для керівників та начальників, забезпечити справедливе керівництво та нести відповідальність за дії чи бездіяльність підлеглих, забезпечити їх сприяння діяльності НАТО, заохочуючи і нагороджуючи тих, хто працював добре, виправляючи тих, хто не відповідає стандартам [9].

Ураховуючи зазначене, на шляху до європейської та євроатлантичної інтеграції артикуляція в нормативно-правовому полі та впровадження в процес фахової підготовки військовослужбовців Збройних Сил України таких євроатлантичних цінностей як єдність, вірність, неупередженість, відповідальність та професіоналізм, дозволять сформувати правову базу для цілеспрямованого впливу на їх свідомість, переконання та професійну поведінку 3 метою формування у них належного морально-психологічного стану, а також спроможності до виконання завдань за призначенням та участі у проведенні спільних бойових дій (операцій) 3 підрозділами НАТО [2].

\section{Висновки.}

3 огляду на вищенаведене, зрозуміло, що європейські цінності та основні етичні принципи Північноатлантичного альянсу значною мірою збігаються 3 етичними принципами, визначеними у Візії розвитку Збройних Сил України. Проте, якщо ми піднімаємось на рівень інтернаціональної етики, принцип патріотизму має розкриватися вже не тільки як цінність вірності та служіння окремому народу i державі, а як цінність єдності і вірності професійному колективу, військовій організації, всім країнам-членам та партнерам, інтересам Альянсу, інтернаціональним зобов'язанням та людству в цілому.

Тобто, принцип патріотизму на шляху до євроатлантичної інтеграції набуває інтернаціонального наповнення i вимагає розширення світогляду та формування критичного мислення і відповідних етичних переконань військовослужбовців та працівників, що проходять службу у складі багатонаціональних Впровадження етичних засад та 


\section{Питання психології}

євроатлантичних цінностей у військовопрофесійному середовищі Збройних Сил України вимагає корегування як усієї сфери професійних відносин, так і врахування безпосереднього впливу на формування образу мислення та поведінки суб'єктів цих відносин.

Розширення дефініції поняття «патріотизм» 3 врахуванням вимог та викликів сучасності щодо інтернаціоналізації професійної свідомості військовослужбовців Збройних Сил України $\epsilon$ перспективним напрямком наукових досліджень у філософській, педагогічній та психологічній науках. Авторка закликає наукову спільноту долучатися до фундаментальних досліджень в окресленій галузі, адже сучасний військовослужбовець має бути не тільки патріотом своєї Вітчизни, але й вірним і відданим справі євроатлантичної інтеграції, що вимагає від нього бути обізнаним у етичних вимогах Європейського Союзу та НАТО.

\section{Список використаних джерел}

1. Кримець Л. В. Філософія влади та управління науково-освітнім простором: монографія / Людмила Володимирівна Кримець - К.: Золоті ворота, 2016. - 410 с.

2. Кримець Л. В. Ціннісні аспекти формування ментальності військовослужбовців Збройних Сил України / Л. В. Кримець // Вісник Національного університету оборони України. - 2018. - № 1(49).- С. $155-160$.

3. Кримець Л. В, Пальчик С. І. Аксіологічні аспекти патріотизму в контексті соціального управління: монографія / Л. В. Кримець, С. І. Пальчик. - К. : Поліграфічний центр НУОУ, 2013. - 250 с.

4. Ideology and National Competitiveness. An Analysis of Nine Countries. // Ed. by Lodge Y., Vogel E. - Boston, 1987. - 475p.

5. Doob L. Patriotism and Nazionalism. Their psichological Faundation. / L. Doob. - Yale University, 1964. - P. 62-66.

6. Візія Генерального штабу щодо розвитку Збройних Сил України на найближчі 10 років [електронний ресурс]. - Режим доступу: https:/www.mil.gov.ua/news/2020/01/11/viziya-generalnogoshtabu-zs-ukraini-shhodo-rozvitku-zbrojnih-sil-ukraini-na-najblizhchi-10-rokiv

7. Затверження проєкту Стратегічного оборонного бюлетеня [електронний ресурс]. - Режим доступу: https://www.mil.gov.ua/news/2021/02/11/u-rozroblenomu-v-minoboroni-proekti-strategichnogooboronnogo-byuletenya-viznacheno-perspektivnu-model-zbrojnih-sil-ukraini-zrazka-2030-roku/

8. Професійна та гендерна ментальність військовослужбовців Збройних Сил України: формування на засадах європейських цінностей : навчальний посібник / під заг. ред. Л. В. Кримець. К.: НУОУ, 2018. - $188 \mathrm{c.}$

9. NATO Code of Conduct [електронний ресурс]. - Режим доступу: https://www.nato.int/structur/recruit/info-doc/code-of-conduct.pdf.

\section{References}

1. Krymets' L. V. Filosofiya vlady ta upravlinnya naukovo-osvitnim prostorom: monohrafiya [Philosophy of power and management of scientific and educational space] / Lyudmyla Volodymyrivna Krymets' - K.: Zoloti vorota, 2016. - 410 s. (in Ukrainian).

2. Krymets' L. V. Tsinnisni aspecty formuvannya mentalnosti viyskovoslyzhbobtsiv Zbroynykh Syl Ukrayiny / Krymets' L. V. // Visnyk NUOU. - 2018. - № 1(49).- S. 155-160. (in Ukrainian).

3. Krymets' L. V, Pal'chyk S. I. Aksiolohichni aspekty patriotyzmu v konteksti sotsial'noho upravlinnya: monohrafiva [Axiological aspects of patriotism in the context of social governance] / L. V. Krymets', S. I. Pal'chyk. - K. : Polihrafichnyy tsentr NUOU, 2013. - 250 c. (in Ukrainian).

4. Ideology and National Competitiveness. An Analysis of Nine Countries. // Ed. by Lodge Y., Vogel E. - Boston, 1987. - 475p. (in USA).

5. Doob L. Patriotism and Nazionalism. Their psichological Faundation. / L. Doob. - Yale University, 1964. - P. 62-66. (in USA).

6. Viziya Heneralnoho shtabu schodo rozvytku Zbroynykh Syl Ukrayiny [electronnyi resurs]. - Rezhim dostupu: https://www.mil.gov.ua/news/2020/01/11/viziya-generalnogo-shtabu-zs-ukraini-shhodo-rozvitkuzbrojnih-sil-ukraini-na-naiblizhchi-10-rokiv (in Ukrainian).

7. Zatvergenva provektu Stratehichnoho oboronnoho buletenvia 「electronnvi resurs]. - Rezhim dostupu: 「https://www.mil.gov.ua/news/2021/02/11/u-rozroblenomu-v-minoboroni-proekti-strategichnogooboronnogo-byuletenya-viznacheno-perspektivnu-model-zbrojnih-sil-ukraini-zrazka-2030-roku/ Ukrainian).

8. Profesiyna ta genderna mentalnisti viyskovoslyzhbobtsiv Zbroynykh Syl Ukrayiny : navchalnyi posibnyk / pid zag. red. Krymets' L. V. - K.: NUOU, 2018. - 188 s. (in Ukrainian).
Code
of Conduct
「electronnyi
resurs].
Rezhim dostupu:

https://www.nato.int/structur/recruit/info-doc/code-of-conduct.pdf. 


\section{Питання психології}

\section{Резюме}

Крымец Л. В. доктор философских наук, старший научный сотрудник, ведущий научный сотрудник НДЛ (соииально-гуманитарныхх проблем) кафедры общественных наук Национального университета обороны Украины имени Ивана Черняховского

\section{ПРИНЦИП ПАТРИОТИЗМА В КОНТЕКСТЕ АКТУАЛИЗАЦИИИ ЕВРОАТЛАНТИЧЕСКИХ ЦЕННОСТЕЙ В ВООРУЖЕННЫХ СИЛАХ УКРАИНЫ}

Внедрение этических принципов и евроатлантических иенностей в военно-профессиональной среде Вооруженных Сил Украины требует корректировки как всей сферы профессиональных отномений, так и учета непосредственного влияния на формирование образа мышиения и поведения субъектов этих отношений. На международном уровне приниип патриотизма раскрывается через иенности единства и верности коллективу, военной организачии, странам-иленам и партнерам, интересам Альянса, международным обязательствам и человечеству в целом. То есть, приниип патриотизма на пути евроатлантической интеграции приобретает интернациональное наполнение и требует расширения кругозора и формирования критического мышления и соответствующих этических убеждений военнослужаших.

Ключевые слова: патриотизм; верность; евроатлантические иенности; профессиональная этика; демократизачия украинского войска; военная деятельность.

\section{Summary}

Krymets L. Doctor of Science in Philosophy, Senior Researcher

Chief Researcher of the Research Laboratory

(Social and Humanitarian Problems) of the Humanitarian Institute

National Defense University of Ukraine named after Ivan Chernyakhovskyi

\section{THE PRINCIPLE OF PATRIOTISM IN THE CONTEXT OF THE ACTUALIZATION OF} EURO-ATLANTIC VALUES IN THE ARMED FORCES OF UKRAINE

Introduction. The introduction of ethical principles and Euro-Atlantic values in the military-professional environment of the Armed Forces of Ukraine requires adjustment of the entire sphere of professional relations and taking into account the direct influence on the formation of thinking and behavior of the subjects of these relations.

Purpose. The goal of the article is description of international aspects of the patriotism principle into military servicemen mentality formation in the Armed Forces of Ukraine on the way of The NATO integration.

Methods. Methodologically, the author proceeds from the position of the sociocultural approach that the change in external conditions and environment inevitably entails changes (positive or negative) of the inner world of the individual, personal formations, that is, a change in the motivational and value sphere of the personality under the influence of socio-cultural factors leads to a transformation of mentality.

The author pays special attention to the analysis of contemporary democratic values defined in the ethical code "The NATO Code of Conduct" among which unity, impartiality, loyalty, responsibility and professionalism are considered basic. These five core values constitute the axiological basis of the Code of Ethics, which defines the requirements for the conduct of civilian and military personnel of all NATO units.

Originality. Patriotism - defending the national interests of the state, respect and love for the Motherland, its state symbols, national values, culture, history, language, ideological conviction, devotion, willingness to sacrifice for the freedom and independence of people. At the international level, the principle of patriotism is revealed through the values of unity and loyalty to the professional community, the military organization, member countries and partners, the interests of the Alliance, international commitment and humanity as a whole.

Conclusion. That is, the principle of patriotism acquires an international content and requires the expansion of worldview and the formation of critical thinking and relevant ethical beliefs of servicemen and employees serving in multinational contingents. Articulation in the normative-legal field and introduction in the process of professional training of servicemen of the Armed Forces of Ukraine of the principle of patriotism and such Euro-Atlantic values as unity, loyalty, impartiality, responsibility and professionalism will allow to form a legal basis for purposeful influence on their consciousness and conviction. formation of their proper moral and psychological condition, as well as the ability to perform the tasks assigned to them and participate in joint combat operations with NATO units.

Key words: patriotism; loyalty; Euro-Atlantic values; professional ethics; democratization of the Ukrainian arm; military activity.

Recelved/Поступила: 24.02. 21. 